\title{
Utilization of Waste Heat Recovery in Jordan Cement Factories
}

\author{
O.Aljaloudi, I. Al-Hinti
}

\begin{abstract}
This research aims to investigate the potential of using the exhaust gases generated through the cement industry, to reduce the electricity consumption rate of the grid in the cement factory using a suggested design of thermodynamic cycle, which will lead to an improvement of the overall energy efficiency in the plant. Results showed that simple Rankine cycle came up to have the highest efficiency which is equal to $21 \%$ and the most suitable cycle to cement factories with production capacity equal to 3500 ton/day of clinker or more where the temperature range of the cooler exhaust gases is (300-420) ${ }^{\circ} \mathrm{C}$.
\end{abstract}

\section{INTRODUCTION}

Cement production is one of the most energy intensive industrial processes. A considerable amount of energy input is lost through different parts of the processing units such as preheater stack, rotary kiln shell and clinker cooler stack. The recovery and utilization of waste heat not only conserves fuel, usually fossil fuel, but also reduces the amount of waste heat and greenhouse gases dumped to the environment. The priority in the cement industry is to minimize the increase in energy expenditure, to be more efficient and good competitor both internally and internationally. Also in current circumstances, both the availability and cost of energy is becoming challenge to local industrial hubs. In many countries, energy costs represent the largest component of direct production cost for cement. Energy cost represents as much as $40 \%$ to $60 \%$ of cement direct production cost [1]. Energy cost is incurred due to the need for large quantities of thermal heat for the clinkerization, calcination and drying processes and electrical energy for operation of motors for grinding mills, fans, conveyers and other motor driven equipment. Although the fuel use and energy use will depend on the type of process, equipment, system efficiency and fuel heating value, typical requirements for coal use is in the range of $150-250 \mathrm{~kg}$ per metric tons of cement and typical requirements for electrical energy use is in the range of 80$125 \mathrm{kWh}[2]$.

\section{WASTE HEAT RECOVERY IN CEMENT INDUSTRY}

Jordanian cement plants has had to deal with a number of challenges over the past few years, including increased competition, rising production costs, slowing cement demand, demands from employees and pressure by environmental activists. The most challenging aspect of this competition was that one firm was granted a licence by the

Revised Manuscript Received on August 05, 2019.

O. Aljaloudi, Department of Mechanical and Maintenance Engineering, German Jordanian University, Jordan. (Email: Ohoud.aljaloudi@gju.edu.jo)

I. Al-Hinti, Department of Mechanical and Maintenance Engineering, German Jordanian University, Jordan. (Email: Ismael.Hinti@gju.edu.jo) authorities to import clinker - the main material used in the production of cement - from neighbouring countries, where the cost of producing it is a fraction of the cost of producing it in Jordan. At the same time, demand for cement dropped following the onset of the 2008 global financial crisis, which led to a marked reduction in activity in the kingdom's construction and property development sector.

Fuel costs account for around $70 \%$ of Jordanian cement plants variable production costs, and that has created a severe problem not only for Jordanian cement plants but also for the Jordanian industrial sector as a whole because the kingdom imports all of its oil at market prices, which have risen considerably over the last few years.

Electricity is considered the main energy source in cement industry and the cost of electrical energy varies with the consumption time especially for the industrial customers. For example, in Jordan the electricity tariff of one KWh can vary between 197 and 264 Fils between day and night [3].

Heat recovery in cement factories is not a new topic that has been worked along with in the world. However, the design and analysis extent of research in this topic is still limited in Jordan. The significance of this investigation is to propose an optimal cycle that will carefully take into account the specific characteristics of cement industry in Jordan.

The case considered in this research is a Jordanian cement plant has a full cement process line from mining to cement finish grinding. This plant was established in 2009. It has a production capacity of 2500 tons of clinker per day. The high cooler exit gas temperature has to be cooled through passing through heat exchanger before directing to the atmosphere.

The plant consumes on average 36.1 (kWh) of electrical energy per month (clinker production) and all of which comes from the national grid.

\section{PLANT PARAMETERS ANALYSIS}

Power available for recovery depends on several factors: Capacity of kiln, how many ton of clinker produces per day, and the efficiency of the cement plant.

The amount of heat that can be utilized from the waste cooler exhaust gases is calculated using this equation:

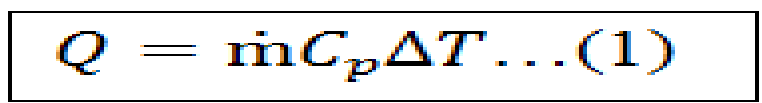

During to the phase change inside the heat power cycle (CHP), that must be used to extract and convert the waste

Published By:

Blue Eyes Intelligence Engineering

\& Sciences Publication 
heat to useful electrical power, following equation used to calculate the amount of thermal energy utilized by the (CHP):

$$
Q=\dot{\mathrm{m}} \Delta h \ldots(2)
$$

Main process parameters of the case

\begin{tabular}{|lcc|}
\hline The Case & \\
\hline $\begin{array}{l}\text { Clinker } \\
\text { production } \\
\text { Cooler flow }\end{array}$ & $\mathbf{3 0 0 0}$ & Ton/day \\
Gas flow & 194077 & $\mathrm{Nm}^{3} / \mathbf{h}$ \\
Temp & 330 & ${ }^{\circ} \mathrm{C}$ \\
\hline
\end{tabular}

\section{SIMULATION MODEL \& RESULTS}

The thermal energy analysis of the cooler exhaust waste gas stream was conducted and it was found that it contains $7368 \mathrm{~kJ} / \mathrm{kg}$ clinker of thermal energy, at $330^{\circ} \mathrm{C}$. Three different alternatives (simple Rankine cycle, organic Rankine cycle, Kalina cycle) for recovering waste heat from THE CASE factory have been examined using simulation model by hysys software.

The overall results for simple Rankine cycle simulation of the case plant were very satisfactory as shown in table 1 . Since the electric power that can be generated from combined cycles depends mainly on the exhaust gasses flow rate and its temperature .Depending on Hysys software, the pressure of the steam-water working fluid was limited between (2000-8000) $\mathrm{kPa}$ while the optimal value was 4000 $\mathrm{kPa}$. Net output electric power came up to be $2069 \mathrm{~kW}$ with overall efficiency of the Rankine cycle.

Table 1 : Main Results of (RC) - The Case Plant

\begin{tabular}{|c|c|c|}
\hline Description & units & value \\
\hline $\begin{array}{l}\text { Exhaust gases } \\
\text { flow rate }\end{array}$ & $\mathrm{kg} / \mathrm{sec}$ & 31.2 \\
\hline $\begin{array}{l}\text { Working fluid } \\
\text { flow rate }\end{array}$ & $\mathrm{kg} / \mathrm{sec}$ & 2.8 \\
\hline $\begin{array}{cc}\text { Exhaust } & \text { gas } \\
\text { temperature } & \end{array}$ & ${ }^{\circ} \mathrm{C}$ & 330 \\
\hline$W_{\text {turbine }}$ & $\mathrm{kW}$ & 2111 \\
\hline$W_{\text {pump }}$ & $\mathrm{kW}$ & 14.63 \\
\hline $\begin{array}{l}\text { Optimum Max. } \\
\text { pressure inside the } \\
\text { cycle }\end{array}$ & $\mathrm{kPa}$ & 4000 \\
\hline
\end{tabular}

The same analysis was made for the case Plant using Organic Rankine Cycle. The pressure of the ORC was also limited between (2000-8000) while the optimal value came up to be $5800 \mathrm{kPa}$. Net output electrical power is $1134.4 \mathrm{~kW}$ while overall efficiency is equal to $11.7 \%$. Detailed output results are shown in table 2.

\begin{tabular}{llc}
\multicolumn{2}{c}{ Table 2: Main results of (ORC) } & - The Case Plant \\
\hline Description & units & value \\
\hline $\begin{array}{l}\text { Exhaust gases } \\
\text { flow rate }\end{array}$ & $\mathrm{Kg} / \mathrm{sec}$ & 31.2 \\
$\begin{array}{l}\text { Working fluid } \\
\text { flow rate }\end{array}$ & $\mathrm{Kg} / \mathrm{sec}$ & 8.96 \\
$\begin{array}{l}\text { Exhaust gas } \\
\text { temperature } \\
\boldsymbol{W}_{\text {turbine }}\end{array}$ & ${ }^{\circ} \mathrm{C}$ & 330 \\
\multicolumn{1}{c}{$\boldsymbol{W}_{\text {pump }}$} & $\mathrm{kW}$ & 1245 \\
$\begin{array}{l}\text { Optimum } \\
\text { Max. pressure } \\
\text { inside } \\
\text { cycle }\end{array}$ & $\mathrm{Kpa}$ & 110.6 \\
\hline
\end{tabular}

Same analytical procedure was made on the case plant using Kalina cycle. The pressure range in this cycle was between (2500-10000) kpa while the optimal value was 5000-kpa.Net output electrical power is $977.34 \mathrm{~kW}$ while overall efficiency is equal to $10.1 \%$ see fig. 2 .

Table 3 shows the output power generated after the optimization process and all main results

.Table 3: Main results of (KC) - The Case Plant

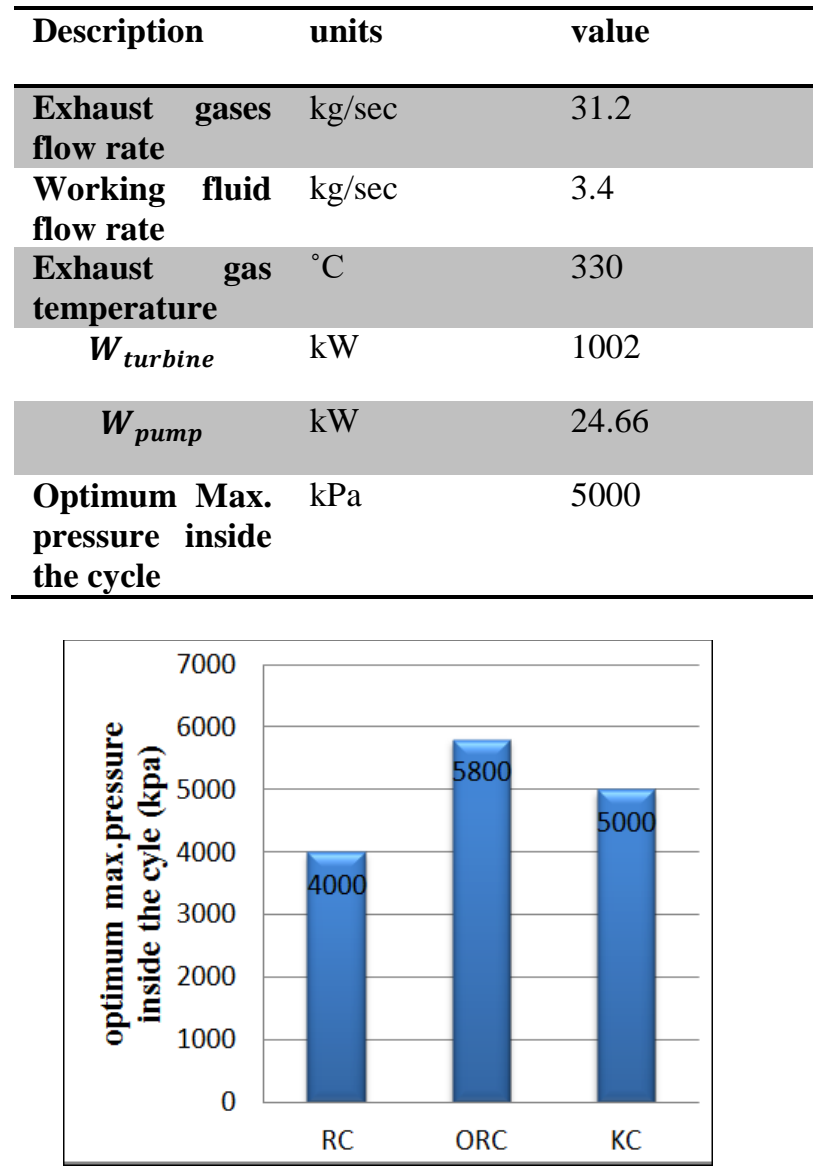

Figure 1: The optimum maximum pressure for each cycle 


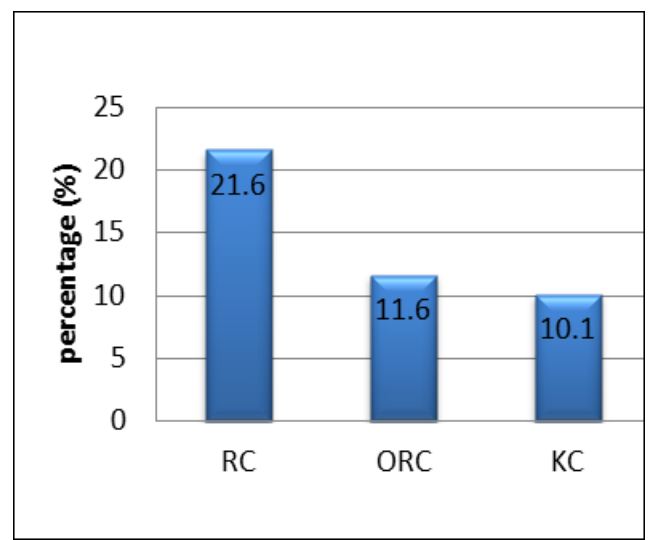

Figure 2: Efficiency comparisons between Suggested Cycles

\section{ECONOMIC FEASIBILITY}

The installation cost for RC is in range from 2000 to 4000 $\$$ per $\mathrm{kW}$ produced as stated in [4] By taking the upper limit $4000 \$ / \mathrm{kW}$, the installation cost for $2000 \mathrm{~kW}$ output power system is $(5,672,000) \mathrm{JOD}$.The Operation and Maintenance (O\&M) cost of components are estimated to be in the range of $\$ 0.005$ to $\$ 0.020 / \mathrm{kWh}$ as given in [4]. Rankine cycle power systems themselves have relatively low maintenance costs. Therefore, assuming that O\&M cost is $0.0125 \$ / \mathrm{kWh}$ per year, which means that the O\&M cost for this project is 114125 JD per year. The net present Value of the project, Assuming that the life of the project is 20 years is $11,428,249.8 \mathrm{JD}$ with payback period aroound 4 years.

\section{CONCLUSION}

The most suitable system for the volume and temperature of gas of the case plant was the simple Rankine cycle with a gross efficiency $21.6 \%$. The second studied system was organic Rankine cycle with n-pentane as a working fluid, the result shows that this system was the second best choice for that case with net output electrical power $1134.4 \mathrm{~kW}$ and overall efficiency equal to $11.7 \%$.In addition, another system has been studied is Kalina system and the results shows that the net electrical output $977.34 \mathrm{~kW}$ with $10.1 \%$ as a gross efficiency which means that was the worst choice.

\section{REFERENCES}

1. PO. M. AL-RABGH, M. BEmUTTV, M. AKVURT, Y. NAJJAR and T. ALP, "RECOVERY AND UTILIZATION OF WASTE HEAT," Heat Recovery Systems \& CHP, vol. Vol. 13, pp. 463-470, 1992.

2. M. Sathiyamoorthy and M. Biglari, "A CASE STUDY: THE WASTE HEAT RECOVERY AND UTILIZATION FOR POWER," International Journal of Advanced Research in GENERATION IN A CEMENT PLANT (PHASE-1), pp. 1-26, 2016

3. "The Ministry of Energy and Mineral Resources," 77 2017. [Online]. Available: http://www.memr.gov.jo/Default.aspx.

4. D. Lombardi, L. Porter and A. Barber, "Conceptualising Sustainability in UK," Urban studies, 2010. 